\title{
Physical properties of a new resin-based root canal sealer in comparison with AH Plus Jet
}

\author{
Myint Thu, Jin-Woo Kim, Se-Hee Park, Kyung-Mo Cho* \\ Department of Conservative Dentistry, College of Dentistry, Gangneung-Wonju National University, Gangneung, Republic of Korea
}

\begin{abstract}
Purpose: The aim of this study was to assess the physical properties of a novel resin-based endodontic sealer, Any-Seal, in comparison with AH Plus Jet. Materials and Methods: Flow, radiopacity and compressive strength were examined according to ISO 6876/2001. For flow test, $0.05 \mathrm{~mL}$ of sealer was placed between glass plate and $100 \mathrm{~g}$ weight were applied. Ten minutes after mixing the sealers, the load was removed and the diameters of the compressed sealer discs were measured. For radiopacity, 10 $\mathrm{mm}$ diameter and $1 \mathrm{~mm}$ thickness sample were fabricated and took radiograph with an aluminum step-wedge and analyzed using imaging program. For compressive strength test, $4 \mathrm{~mm} \times 6 \mathrm{~mm}$ cylindrical specimen was fabricated and tested after 24 hours and 1 week using Universal testing machine. Results: Both tested sealers were consistent with ISO 6876/2001 in the flow and radiopacity test. The flow values of both sealers were not significantly different $(P>0.05)$. AH Plus Jet had significantly higher radiopacity $(P<0.05)$. AH Plus Jet showed higher compressive strength at both time intervals $(P<0.05)$. Conclusion: Any-Seal showed low compressive strength until after 1 week, so its physical and biological aspect should be evaluated more before clinical use. (J Dent Rehabil Appl Sci 2017;33(2):80-7)
\end{abstract}

Key words: AH Plus Jet; Any-Seal; compressive strength; flow; radiopacity

\section{Introduction}

Obturating the instrumented canal with endodontic sealer is an important step in endodontic treatment to achieve a fluid-tight or hermetic seal both apically and laterally. ${ }^{1}$ Proper sealing action with sealers prevents apical leakage, reduces inflammation, minimizes the invasion of residual bacteria into the periapical tissues and resolves periapical lesions. ${ }^{2}$ Hence, sealers should have certain characteristics to achieve an effective seal. ${ }^{2}$ As stated by Grossman, an ideal endodontic sealer should have an excellent seal, radiopacity, a slow setting time, insolubility in tissue

*Correspondence to: Kyung-Mo Cho

Professor, Department of Conservative Dentistry, College of Dentistry, Gangneung-Wonju National University, 7, Jukheon-gil, Gangneung, 25457, Republic of Korea

Tel: +82-33-640-3156, Fax: +82-33-640-3102, E-mail: drbozon@gwnu.ac.kr

Received: February 26, 2017/Last Revision: April 13, 2017/Accepted: April 26, 2017 fluids, adequate adhesion between the canal wall and the filling materials, and suitable biological properties. ${ }^{3}$ Furthermore, adequate flow and mechanical strength are desirable for clinical reasons. ${ }^{4}$ Currently, a wide range of endodontic sealers with different bases is available: silicone, bioceramic, zinc oxide eugenol, glass ionomer, calcium hydroxide and resin.

Among these options, resin-based sealers are superior due to their excellent physicochemical properties. ${ }^{5}$ The AH series has been the most successful resin-based sealer for over half a century. ${ }^{6} \mathrm{AH}$ Plus Jet (DENTSPLY De Trey, Konstanz, Germany) is an innovation based on the well-established AH Plus

Copyright@ 2017 The Korean Academy of Stomatognathic Function and Occlusion. (c) It is identical to Creative Commons Non-Commercial License. 
sealer with the same chemical compositions. As stated by the manufacturer, its new double-barrel syringe reduces hand-mixing variables. Automatic mixing provides better homogenization of the pastes in an ideal ratio and improves the physicochemical properties of the sealers. ${ }^{7}$

Recently, a new resin-based endodontic sealer with mixing syringe, Any-Seal (Mediclus, Cheongju, Korea), was launched into the market. According to the manufacturer, it consists of ethylene glycol salicylate, epoxy oligomer resin, zirconium oxide and calcium phosphate. However, limited information is available on the physical and mechanical properties of AnySeal.

A new endodontic sealer being introduced into the market must be compared with frequently used sealers to evaluate its properties. ${ }^{8}$ The maneuvering and clinical behavior of endodontic sealers may be examined by performing laboratory tests on their properties. 'The objective of this laboratory study was to assess the selected physical and mechanical properties of the newly introduced sealer Any-Seal, including flow, radiopacity and compressive strength, in comparison with AH Plus Jet.

\section{Materials and Methods}

$\mathrm{AH}$ Plus Jet and the new endodontic sealer AnySeal were used in this study (Table 1). The properties flow, radiopacity and compressive strength were selected and examined.

\section{Flow test}

The flow was evaluated according to ISO 6876/ 2001. A volume of $0.05 \pm 0.005 \mathrm{~mL}$ of each tested sealer was placed on a glass plate $(40 \times 40 \times 5 \mathrm{~mm})$ using a graduated disposable $1 \mathrm{~mL}$ syringe. Three minutes later, another glass plate weighing $20 \pm 1 \mathrm{~g}$ and a $100 \mathrm{~g}$ weight were applied on top of the sealer. Ten minutes after mixing the cement, the load was removed, and the maximum and minimum diameters of the compressed sealer discs were measured using a digital caliper (Mitutoyo, Mitutoyo Cop, Kawasaki, Japan). The test was repeated if both diameters did not fall within $1 \mathrm{~mm}$, and three tests were performed for each sealer (Fig. 1).

\section{Radiopacity}

The radiopacity test was performed in accordance

Table 1. Manufacturers and composition of the tested sealers

\begin{tabular}{cll}
\hline Material & \multicolumn{1}{c}{ Composition } & Manufacturer \\
\hline \multirow{2}{*}{ AH Plus Jet } & $\begin{array}{l}\text { Paste A: epoxy resin; calcium tungstate; zirconium oxide; aerosol; iron oxide } \\
\text { Paste B: 1-adamantane amine; 'N,N-dibenzyl-5-oxa- nonandiamine-1,9; TCD- } \\
\text { diamine; calcium tungstate; zirconium oxide; aerosol; silicone oil }\end{array}$ & $\begin{array}{l}\text { DENTSPLY, De Trey, } \\
\text { Konstanz, Germany }\end{array}$ \\
$\begin{array}{l}\text { epoxy oligomer resin; ethylene glycol salicylate; zirconium oxide; calcium } \\
\text { phosphate }\end{array}$ & $\begin{array}{l}\text { Mediclus, Cheongju, } \\
\text { Korea }\end{array}$ \\
\hline
\end{tabular}

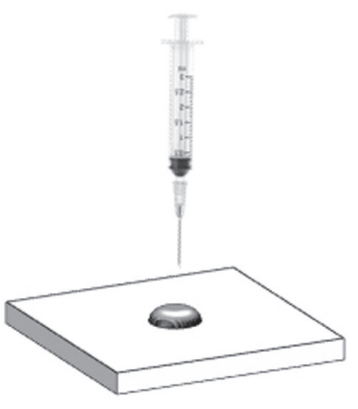

Drop $1 \mathrm{~mL}$

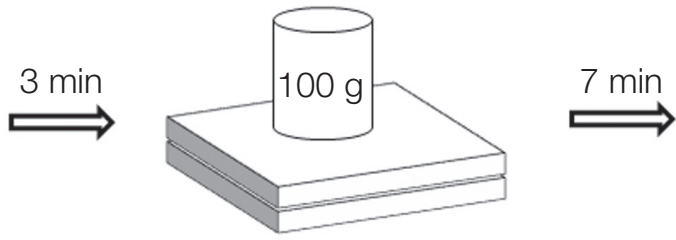

Fig. 1. Schematic drawing of the flow test. 
with the specifications of ISO $6876 / 2001$. Three specimens with $10 \mathrm{~mm}$ diameter and $1 \mathrm{~mm}$ thickness were fabricated for each sealer using metallic ring molds. Samples were incubated $\left(37^{\circ} \mathrm{C}, 95 \%\right.$ humidity) until completely set. The specimens were positioned on a digital X-ray sensor (Kodak RVG 6100, Marne la Vallée Cedex, France) along with an aluminum step-wedge graduated from 1 to $10 \mathrm{~mm}$ in 1 $\mathrm{mm}$ increments. Radiographs were taken using an Xray machine (UL Medical Equipment Ltd, Fremont, USA) operating at $70 \mathrm{kV}, 7 \mathrm{~mA}, 1$ second exposure time and $300 \mathrm{~mm}$ focus-sensor distance. The radiopacity value was assessed using an imaging program (Infinit G3 PACS, Seoul, Korea) (Fig. 2).

\section{Compressive strength}

Twenty cylindrical specimens with $4 \mathrm{~mm}$ diameter and $6 \pm 1 \mathrm{~mm}$ height were produced for each sealer group. Half of each group was kept in the incubator $\left(37^{\circ} \mathrm{C}, 95 \%\right.$ humidity) for 24 hours and half for 1 week. The specimens were checked visually without magnification for air voids or chipped edges. Specimens with any such defects were discarded. The diameter of each specimen was calculated by taking the mean of two measurements at right angle to each other to achieve an accuracy of ( \pm 0.01) mm using a digital caliper.

The compressive strength test was performed using the Universal Testing Machine (R\&B, Daejon, Korea) with a load of $800 \mathrm{~kg}$ and cross head speed of $1 \mathrm{~mm} / \mathrm{min}$. The maximum force exerted when the specimen fracture occurred was noted, and the compressive strength was calculated in megapascals using the following formula:

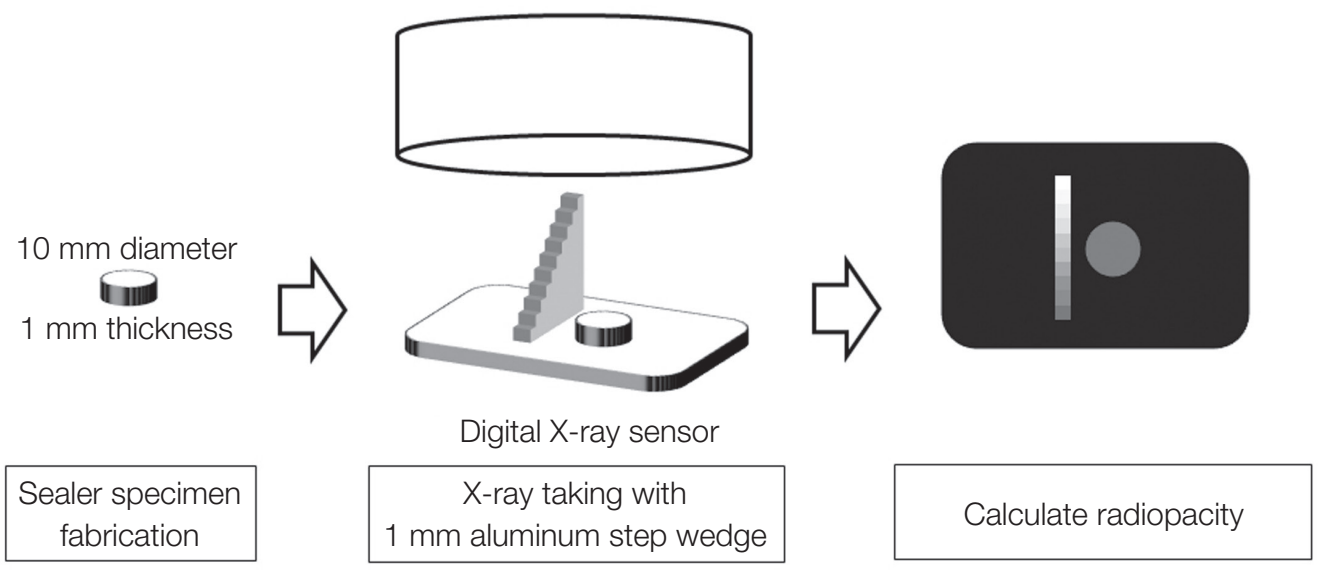

Fig. 2. Schematic drawing of the radiopacity test.
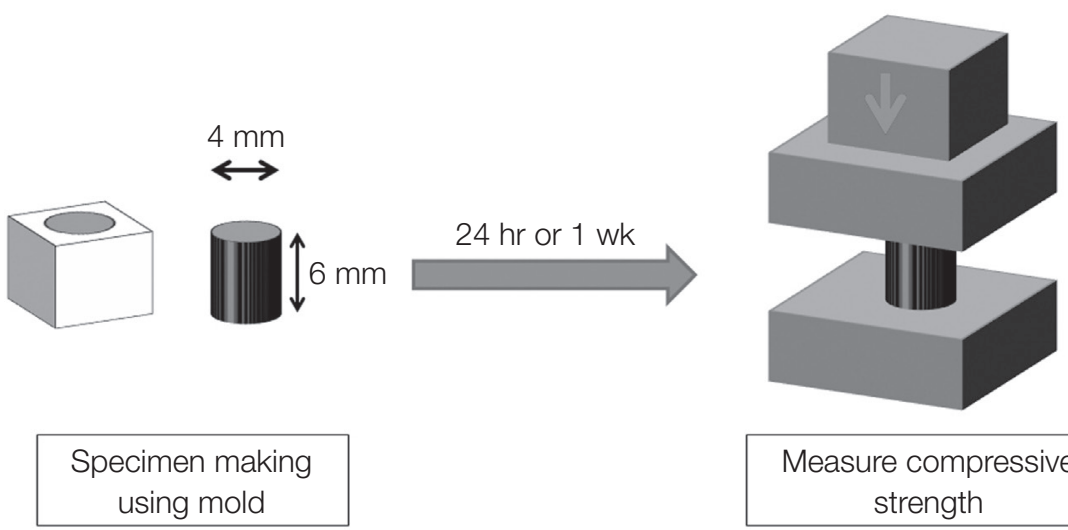

Fig. 3. Schematic drawing of the compressive strength test. 


$$
\mathrm{C}=4 \mathrm{P} / \pi \mathrm{D}^{2}
$$

Where $\mathrm{P}$ is the maximum force applied in newtons, and $\mathrm{D}$ is the measured diameter of the specimen in millimeters (Fig. 3).

\section{Statistical analysis}

The Independent- $T$ test was used to analyze the data in SPSS Statistics Ver. 23 (IBM, New York, USA). The significance level was set at 0.05 .

\section{Results}

The flow and radiopacity results satisfied the specifications of ISO 6876/2001. The mean and standard deviation of the flow $(\mathrm{mm})$ is shown in Table 2. The flow values of AH Plus Jet and Any-Seal were not significantly different $(P=0.47)$. The flow of AnySeal did not agree with the flow value $(40 \mathrm{~mm})$ given in the manufacturer's instructions, performed using the same standardized test. The mean and standard deviation of the radiopacity $(\mathrm{mm} \mathrm{Al})$ is shown in Table 3. The radiopacity of AH Plus Jet was significantly higher than Any-Seal $(P=0.008)$. The radiopacity value of Any-Seal in this study followed the value $(6 \mathrm{~mm} \mathrm{Al})$ given by manufacturer. Table 4

Table 2. Mean and standard deviation of the flow ( $\mathrm{mm}$ ) of the tested sealers

\begin{tabular}{ccc}
\hline & AH Plus Jet & Any-seal \\
\hline Flow & $22.52(0.29)$ & $22.74(0.65)$ \\
\hline
\end{tabular}

Table 3. Mean and standard deviation of the radiopacity $(\mathrm{mm} \mathrm{Al})$ of the tested sealers

\begin{tabular}{ccc}
\hline & AH Plus Jet & Any-seal \\
\hline Radiopacity & $9.33 *(1.15)$ & $5.66(0.57)$ \\
\hline * statistically significantly different $(P<0.05)$. &
\end{tabular}

Table 4. Mean and standard deviation of compressive strength $(\mathrm{MPa})$ of tested sealer groups

\begin{tabular}{ccc}
\hline & $24 \mathrm{hr}$ & $1 \mathrm{wk}$ \\
\hline AH Plus Jet & $28.83^{*}(4.76)$ & $68.95^{*}(15.93)$ \\
Any-Seal & $0.62(0.16)$ & $2.74(1.01)$ \\
\hline
\end{tabular}

* statistically significantly different $(P<0.05)$. shows the mean and standard deviation of the compressive strength of four experimented groups. AH Plus Jet showed higher compressive strength for both 24 hours and 1 week than Any-Seal $(P=0.000)$. The compressive strength values in increasing order were Any-Seal 24 hours $<$ Any-Seal 1 week $<$ AH Plus Jet 24 hours $<$ AH Plus Jet 1 week.

\section{Discussion}

The main responsibilities of endodontic sealers are sealing the prepared canal and entombing the residual bacteria. ${ }^{10}$ The composition and type of endodontic sealer influence its ability to perform adequately in clinical situations. ${ }^{11}$ A higher success rate of endodontic treatment may be associated with enhanced physical properties of endodontic sealers and with certain diagnoses. ${ }^{12}$ Laboratory tests on the properties of endodontic sealer provide a better understanding of its clinical comportment and manipulation. ${ }^{11}$ Two systematized specifications, ISO 6876 and ANSI/ADA \# 57, are frequently used to examine the physical properties of endodontic sealers in the laboratory. These 2 standards are harmonized, with little difference in the amount of sealer used to evaluate flow and working time $(0.05 \pm 0.005 \mathrm{~mL}$ is required for ISO $6876 / 2001$ and $0.5 \pm 0.05 \mathrm{~mL}$ for ADA no. 57). ${ }^{11}$ The current study was conducted based on ISO 6876/2001.

Flow is a significant characteristic of endodontic sealers, ${ }^{13}$ associated with particle size, temperature, shear rate and time, internal diameter of the tubes and insertion rate. ${ }^{14-18}$ An acceptable flow should be sufficient to reach the canal irregularities, whereas an excessive flow may lead to an increased rate of periapical extrusion of material, which can damage the periapical tissues. ${ }^{19}$ Thixotrophy is defined as a time-dependent shear thinning property in which a constant viscous fluid will flow, and its viscosity will be thin and less viscous when vibrated and churned or under shear stress. It will recover to a more viscous behavior after a finite time or once the stress is removed. AH Plus Jet is designed to be slightly thixotropic to establish stability in the root canal. According to ISO $6876 / 2001$, the tested sealers should 
have diameter greater than $20 \mathrm{~mm}$, and both sealers in the present study were tested in accordance with this requirement. The flow of AH Plus Jet in this study was similar to the investigations of previous studies of AH Plus ${ }^{11}$ and greater than in a followup study. ${ }^{20}$ The flow of Any-Seal was lower than the value described in the manufacturer's instruction.

The radiopacity of endodontic sealers is nonnegotiable, ${ }^{13}$ which improves the procedure to facilitate diagnosis. ${ }^{12}$ The endodontic sealer should have adequate radiopacity to be distinguished from the nearby anatomic structure. ${ }^{21}$ Composition and filler concentration are significant factors in the radiopacity of dental materials. ${ }^{12}$ The chemical structure of radiopacifying agents in dental materials should have wide tolerances because the atomic number or relative mass affects the radiopacity. ${ }^{22}$ However, the synergy among the radiopacifying agents determines the final radiopacity. ${ }^{23}$ The radiopacity of $1 \mathrm{~mm}$ aluminum is equivalent to a $1 \mathrm{~mm}$ thickness of dentine. ${ }^{24}$ Thus, the radiopacity value should be greater than or equal to $3 \mathrm{~mm}$ aluminum, as specified by ISO $6876 / 2001$. The radiopacity values of the sealers used in this study complied with the ISO specification. AH Plus Jet presented a higher radiopacity value than Any-Seal $(P<0.05)$ because AH Plus Jet has radiopacifying agents: zirconium oxide and calcium tungstate. ${ }^{25}$ The synergic effect in the coordination of zirconium oxide and calcium tungstate results in excellent radiopacity. ${ }^{26}$ However, Any-Seal includes only zirconium oxide in its composition. Previous studies of $\mathrm{AH}$ Plus reported radiopacity values ranging from $5.97 \pm 0.24-16 \mathrm{~mm} \mathrm{Al} .{ }^{13,26,27}$

Compressive strength reflects the setting process of dental materials. ${ }^{4}$ The mechanical strength of endodontic sealer is not always recognized as an essential property. ${ }^{2}$ However, high compressive strength can be beneficial to reinforce the instrumented tooth and to withstand the displacement of cones during post and core placement. ${ }^{2}$ In this study, AH Plus Jet had higher compressive strength at both experimental time intervals $(P<0.05)$. This difference may be due to the strong bonds among the resin monomers. ${ }^{28}$ Time and compressive strength are directly proportional in this study; the longer the time, the higher the compressive strength. The 1 week experimental groups of both sealers presented higher compressive strength than the 24 hours experimental groups. Any-Seal had low compressive strength until after 1 week. The particle size of radiopacifying agents may affect the compressive strength. ${ }^{29}$ A higher quantity of monomer interacting during polymerization can hinder the setting process and result in low compressive strength. ${ }^{29}$

The other properties such as cytotoxicity, biocompatibility and sealing ability should be evaluated before clinical use.

\section{Conclusion}

In conclusion, the flow and radiopacity values of the tested sealers fulfilled the ISO requirements. AH Plus Jet had higher radiopacity and compressive strength than Any-Seal. Any-Seal demonstrated unsatisfactory compressive strength, which indicates the setting time of the dental materials.

\section{Acknowledgements}

This work was supported by a grant of 2016 Scientific Research (SR1604) from the Gangneung-Wonju National University Dental Hospital.

\section{ORCID}

Myint Thu http://orcid.org/0000-0003-4646-8015

Jin-Woo Kim http://orcid.org/0000-0002-0004-0710

Se-Hee Park http://orcid.org/0000-0002-4052-4082

Kyung-Mo Cho http://orcid.org/0000-0003-34649425

\section{References}

1. Ørstavik D, Eriksen HM, Beyer-Olsen EM. Adhesive properties and leakage of root canal sealers in vitro. Int Endod J 1983;16:59-63.

2. Branstetter J, von Fraunhofer JA. The physical properties and sealing action of endodontic sealer cements: a review of the literature. J Endod 1982;8: 312-6. 
3. Grossman LI. Endodontic practice. 12th ed. New Delhi; Wolters Kluwer Publishers; 2010. p. 301.

4. Ørstavik D. Physical properties of root canal sealers: measurement of flow, working time, and compressive strength. Int Endod J 1983;16:99-107.

5. Marín-Bauza GA, Silva-Sousa YT, da Cunha SA, Rached-Junior FJ, Bonetti-Filho I, Sousa-Neto MD, Miranda CE. Physicochemical properties of endodontic sealers of different bases. J Appl Oral Sci 2012;20:455-61.

6. Schroeder A. The impermeability of root canal filling material and first demonstrations of new root filling materials. SSO Schweiz Monatsschr Zahnheilkd 1954;64:921-31.

7. De-Deus G, Scelza MZ, Neelakantan P, Sharma S, Neves Ade A, Silva EJ. Three-dimensional quantitative porosity characterization of syringe-versus hand-mixed set epoxy resin root canal sealer. Braz Dent J 2015;26:607-11.

8. Cotti E, Petreucic V, Re D, Simbula G. Cytotoxicity evaluation of a new resin-based hybrid root canal sealer: an in vitro study. J Endod 2014;40:124-8.

9. You SY, Bae KS, Baek SH, Kum KY, Shon WJ, Lee W. Lifespan of one nickel-titanium rotary file with reciprocating motion in curved root canals. J Endod 2010;36:1991-4.

10. Ørstavik D. Materials used for root canal obturation: technical, biological and clinical testing. Endod Topics 2005;12:25-38.

11. Zhou HM, Shen Y, Zheng W, Li L, Zheng YF, Haapasalo M. Physical properties of 5 root canal sealers. J Endod 2013;39:1281-6.

12. Collares FM, Klein M, Santos PD, Portella FF, Ogliari F, Leitune VC, Samuel SM. Influence of radiopaque fillers on physicochemical properties of a model epoxy resin-based root canal sealer. J Appl Oral Sci 2013;21:533-9.

13. Ruiz-Linares M, Bailón-Sánchez ME, Baca P, Valderrama M, Ferrer-Luque CM. Physical properties of AH Plus with chlorhexidine and cetrimide. J Endod 2013;39:1611-4.

14. Weisman MI. A study of the flow rate of ten root canal sealers. Oral Surg Oral Med Oral Pathol 1970; 29:255-61.

15. Watts D, Combe EC, Greener EH. The rheologi- cal properties of polyelectrolyte cements II. Glass ionomers. J Oral Rehabil 1981;8:61-7.

16. Vermilyea SG, de Simon LB, Huget EF. The rheologic properties of endodontic sealers. Oral Surg Oral Med Oral Pathol 1978;46:711-6.

17. Uhrich JM, Moser JB, Heuer MA. The rheology of selected root canal sealer cements. J Endod 1978;4: 373-9.

18. Lacey S, Pitt Ford TR, Watson TF, Sherriff M. A study of the rheological properties of endodontic sealers. Int Endod J 2005;38:499-504.

19. Ørstavik D. Endodontic materials. Adv Dent Res 1988;2:12-24.

20. Sonntag D, Ritter A, Burkhart A, Fischer J, Mondrzyk A, Ritter H. Experimental amine-epoxide sealer: a physicochemical study in comparison with AH Plus and EasySeal. Int Endod J 2015;48:74756.

21. Beyer-Olsen EM, Ørstavik D. Radiopacity of root canal sealers. Oral Surg Oral Med Oral Pathol 1981; 51:320-8.

22. Bowen RL, Cleek GW. X-ray-opaque reinforcing fillers for composite materials. J Dent Res 1969;48: 79-82.

23. Bortoluzzi EA, Guerreiro-Tanomaru JM, Tanomaru-Filho M, Duarte MA. Radiographic effect of different radiopacifiers on a potential retrograde filling material. Oral Surg Oral Med Oral Pathol Oral Radiol Endod 2009;108:628-32.

24. Vivan RR, Ordinola-Zapata R, Bramante CM, Bernardineli N, Garcia RB, Hungaro Duarte MA, de Moraes IG. Evaluation of the radiopacity of some commercial and experimental root-end filling materials. Oral Surg Oral Med Oral Pathol Oral Radiol Endod 2009;108:e35-8.

25. Marin-Bauza GA, Rached-Junior FJ, Souza-Gabriel AE, Sousa-Neto MD, Miranda CE, Silva-Sousa YT. Physicochemical properties of methacrylate resinbased root canal sealers. J Endod 2010;36:1531-6.

26. Cañadas PS, Berástegui E, Gaton-Hernández P, Silva LA, Leite GA, Silva RS. Physicochemical properties and interfacial adaptation of root canal sealers. Braz Dent J 2014;25:435-41.

27. Belli S, Ozcan E, Derinbay O, Eldeniz AU. A comparative evaluation of sealing ability of a new, self- 
etching, dual-curable sealer: hybrid root SEAL (MetaSEAL). Oral Surg Oral Med Oral Pathol Oral Radiol Endod 2008;106:e45-e52.

28. Borges RP, Sousa-Neto MD, Versiani MA, RachedJúnior FA, De-Deus G, Miranda CE, Pécora JD. Changes in the surface of four calcium silicatecontaining endodontic materials and an epoxy resin-based sealer after a solubility test. Int Endod J
2012;45:419-28.

29. Viapiana R, Flumignan DL, Guerreiro-Tanomaru JM, Camilleri J, Tanomaru-Filho M. Physicochemical and mechanical properties of zirconium oxide and niobium oxide modified Portland cementbased experimental endodontic sealers. Int Endod J 2014;47:437-48 


\section{새로운 레진계 근관실러와 AH Plus Jet의 물성 비교}

Myint Thu, 김진우, 박세희, 조경모*

강릉원주대학교 치과대학 치과보존학교실

목적: 이 연구는 새로운 레진계 근관실러인 Any-Seal의 여러 물성을 AH Plus Jet와 비교하여 평가하고자 했다.

연구 재료 및 방법: 흐름성, 방사선 불투과성, 압축 강도를 ISO 6876/2001기준에 의해 측정하였다. 흐름성은 실러 0.05 $\mathrm{mL}$ 를 두 개의 유리판 사이에 놓고 $100 \mathrm{~g}$ 의 무게로 눌러 측정했다. 실러 혼합 10 분 뒤 무게를 제거하고 눌려진 실러의 지 름을 측정했다. 방사선 불투과성은 각 근관실러를 지름 $10 \mathrm{~mm}$, 높이 $1 \mathrm{~mm}$ 의 디스크형 시편으로 만들어 aluminum step wedge와 함께 방사선 촬영을 하여 분석했다. 압축 강도는 각 실러를 $4 \mathrm{~mm}$ 지름과 $6 \mathrm{~mm}$ 높이의 실린더 형태로 만든 다 음 24 시간 후와 1 주일 후에 측정했다.

결과: 두 근관실러의 흐름성과 방사선 불투과성 값은 ISO 6876/2001조건에 맞았다. 흐름성은 AH Plus Jet와 Any-Seal 사이에 통계적으로 유의한 차이가 없었다 $(P>0.05)$. AH Plus Jet가 방사선 불투과성 값을 나타냈다 $(P<0.05) .24$ 시간 후와 1주일 후 모두에서 AH Plus Jet가 더 높은 압축 강도를 보였다 $(P<0.05)$.

결론: Any-Seal이 낮은 압축 강도를 보였으므로 다른 물리적, 생물적 특성에 대해 더 많은 연구가 임상적 활용 전에 필요 할 것으로 생각한다.

(구강회복응용과학지 2017;33(2):80-7)

주요어: AH Plus Jet; Any-Seal; 압축강도; 흐름성; 방사선 불투과성

*교신저자: 조경모

(25457)강원도 강릉시 죽헌길 7 강릉원주대학교 치과대학 치과보존학교실

Tel: 033-640-3156 | Fax: 033-640-3102 | E-mail: drbozon@gwnu.ac. kr

접수일: 2017년 2월 26일 | 수정일: 2017년 4월 13일 | 채택일: 2017년 4월 26일 